\title{
On the Distribution and Host-Plant of Aristotelia subericinella (Duponchel, 1843) (Lepidoptera: Gelechiidae)
}

\author{
Kesran AKIN $^{1 *}$, Erdem SEVEN ${ }^{2}$ \\ ${ }^{1}$ Bitlis Eren University, Faculty of Arts and Sciences, Department of Biology, 13000, Bitlis, Turkey. \\ ${ }^{2}$ School of Tourism and Hotel Management, Batman University, 72060 Batman, Turkey. \\ (ORCID: 0000-0003-2921-948X) (ORCID: 0000-0002-7587-5341)
}

\begin{abstract}
Aristotelia subericinella (Duponchel, 1843), previously known from Ankara, Kahramanmaraş, Siirt, Van, Amasya and Bursa, is recorded for the first time in Bitlis province. Astragalus sp. (Leguminosae) is suggested as new larval host-plant of the species. Pupa, adult, male and female genitalia and habitat pictures are illustrated.
\end{abstract}

Keywords: Aristotelia subericinella, Gelechiidae, Lepidoptera, Astragalus, Bitlis.

\section{Aristotelia subericinella (Duponchel, 1843)'nın (Lepidoptera: Gelechiidae) Yayılışı ve Konukçu Bitkisi Hakkında}

$\ddot{O} \mathbf{z}$

Daha önce Ankara, Kahramanmaraş, Siirt, Van, Amasya ve Bursa'dan bilinen Aristotelia subericinella (Duponchel, 1843) türü Bitlis ilinden ilk kez tespit edilmiştir. Türün yeni larva besin bitkisi olarak Astragalus sp. (Leguminosae) önerilmiştir. Pupa, ergin birey, erkek ve dişi genital ile habitat resimleri verilmiştir.

Anahtar kelimeler: Aristotelia subericinella, Gelechiidae, Lepidoptera, Astragalus, Bitlis.

\section{Introduction}

The Gelechiidae family, in the order Lepidoptera, are small and medium sized moths and represented by 4600 species in approximately 500 genera. Specimens belonging to this family are known to have a scaly probosis and a strongly curved labial palpus [1]. Karsholt et al., [2] divided the family into 7 subfamilies with their molecular studies. However, 6 subfamilies: Anacampsinae, Anomologinae, Apatetrinae, Dichomeridinae, Gelechiinae, Thiotrichinae were analyzed, but Physoptilinae subfamily was not included in the study. The Gelechiidae family is represented by 283 species in Turkey. Of these, 13 species belong to the genus Aristotelia Hübner, [1825]: A. baltica A. Sulcs \& I. Šulcs, 1983, A. cupreella Zerny, 1934, A. decoratella (Staudinger, 1880), A. decurtella (Hübner, [1813]), A. euprepella Zerny, 1934, A. fervidella Mann, 1864, A. jactatrix Meyrick, 1926, A. mirabilis (Christoph, 1888), A. pancaliella (Staudinger, 1871), A. parvula (Staudinger, 1879), A. punctatella (Staudinger, 1879), A. retusella Rebel, 1891 and A. subericinella (Duponchel, 1843) [3]. The genus Aristotelia Hübner, [1825] is represented around the world by about 165 species, including about 30 species from Palearctic. Larvae of the genus have been determined so far on the plant families of Apiaceae, Ericaceae, Empetraceae, Lythraceae, Lamiaceae, Scrophulariaceae, Fabaceae, Plumbaginaceae [4].

Junnilainen et al., [5] stated that A. subericinella spread widely from Central and Southern Europe to the South Ural Region and, appears to be a species complex because of it is three different forms based on the material from the South Ural Region. In addition, it shows distribution in Turkey, the Caucasus, Central Asia and South Siberia eastwards to Mongolia. In Turkey, A. subericinella is known from Ankara, Kahramanmaraş, Siirt, Van [3], Amasya [6] and Bursa provinces [7].

"Corresponding author: kesran@ gmail.com

Recieved: 04.01.2021, Accepted: 13.03.2021 
The known food plants of A. subericinella include: Coronilla, Genista, G. germanica, G. pilosa, Medicago, M. falcata and M. sativa (Leguminosae) [8, 9].

Nemrut Mountain located in the west of Tatvan and Ahlat (Bitlis) districts, and Sivri Hill is the highest point with 3050 meters. Mount Nemrut contains a total of 450 plant species that constitute the Iran-Turanian and Europe-Siberian elements. In addition, due to the microclimate formed in the caldera, it also hosts plant species such as Betula pendula, Populus tremula and Juniperus communis subsp. nana [10]. Besides, Caldera was declared a Natural Monument in 2003 [11].

In this paper, the known larval food plants of Aristotelia subericinella (Duponchel, 1843) is given and, a new larval host plant is proposed. Pictures of the species and its habitat are provided. The distribution of the species is mentioned and, is discovered for the first time in Bitlis province.

\section{Materials and Methods}

During the field studies conducted by the authors to determine the biology of Lepidoptera species in the Nemrut Caldera on 7 July 2018, a pupa was found on Astragalus sp. (Leguminosae) (Figure 1). The pupa was placed and preserved in a transparent plastic box and examined in Bitlis Eren University, Faculty of Arts and Sciences, Zoology Research Laboratory. A female adult emerged from the pupa on July 13, 2018 (Figure 2a). After the specimen was pinned and labelled, it was softened and stretched into standard museum material. In addition, 2 males and 1 female samples, which are in the collection of Bitlis Eren University, Faculty of Arts and Sciences, Zoology Research Laboratory and collected on 07.07.2015 from Bitlis Eren University Campus, which is very close to the Nemrut Caldera, were also evaluated (Figure $2 b$ ). The genital preparations used in the study were prepared according to Robinson [12] (Figure 3).

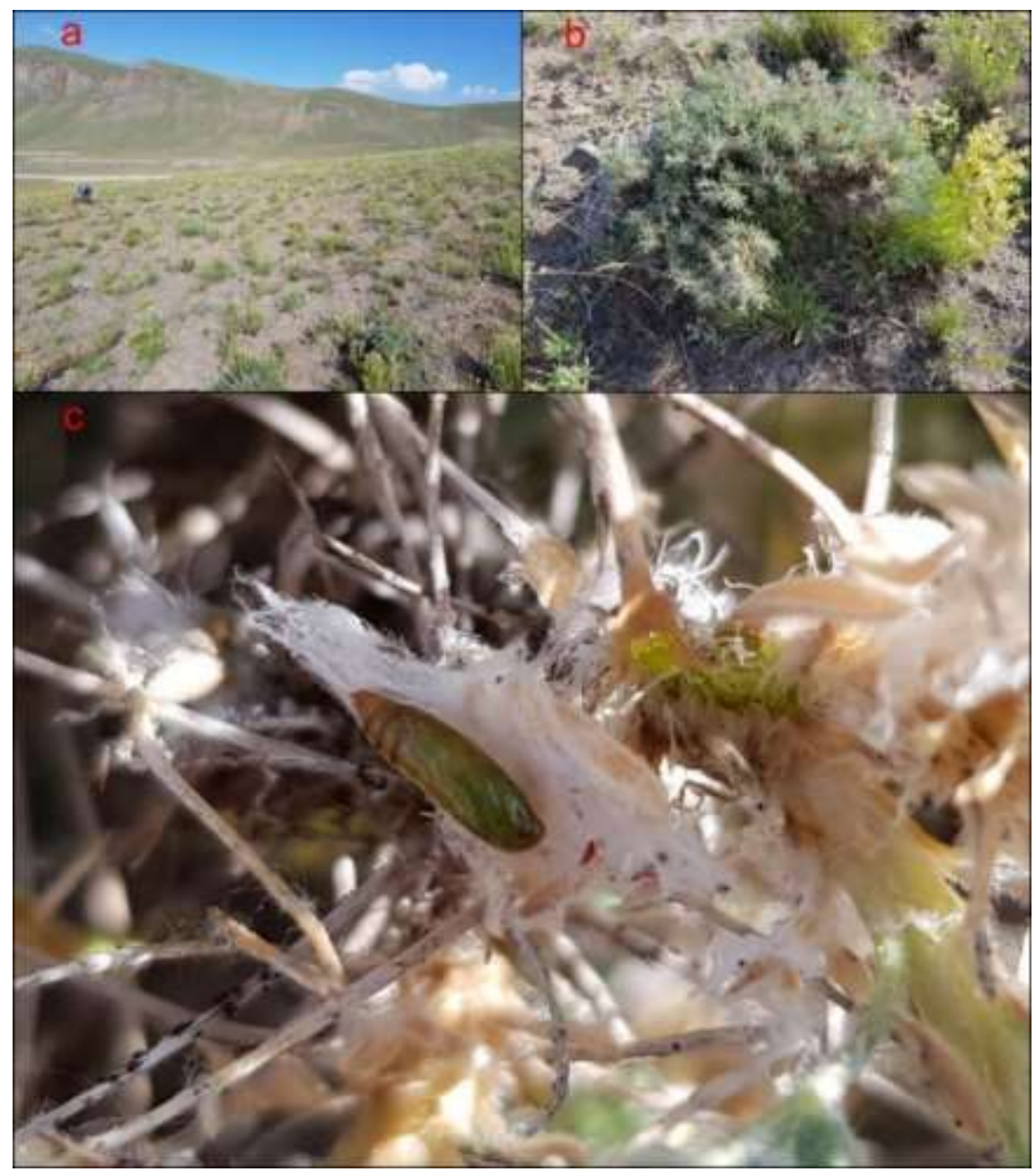

Figure 1. a) Study locality (Nemrut Caldera), b) Astragalus sp. (Leguminaosae (Host-plant)), c) Pupa of $A$. subericinella. 


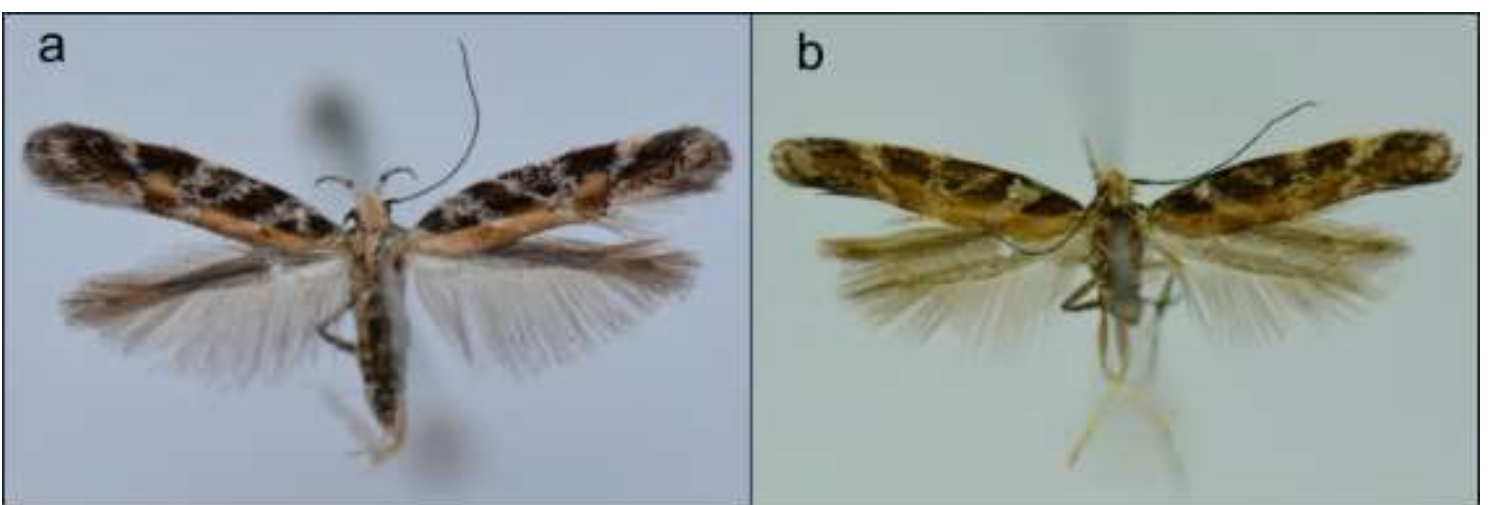

Figure 2. Adults of $A$. subericinella $(13 \mathrm{~mm})$, a. Female specimen emerging from the pupa, b. Male specimen, Bitlis Eren University Campus (Bitlis), 07.07.2015 leg. K. Akın.

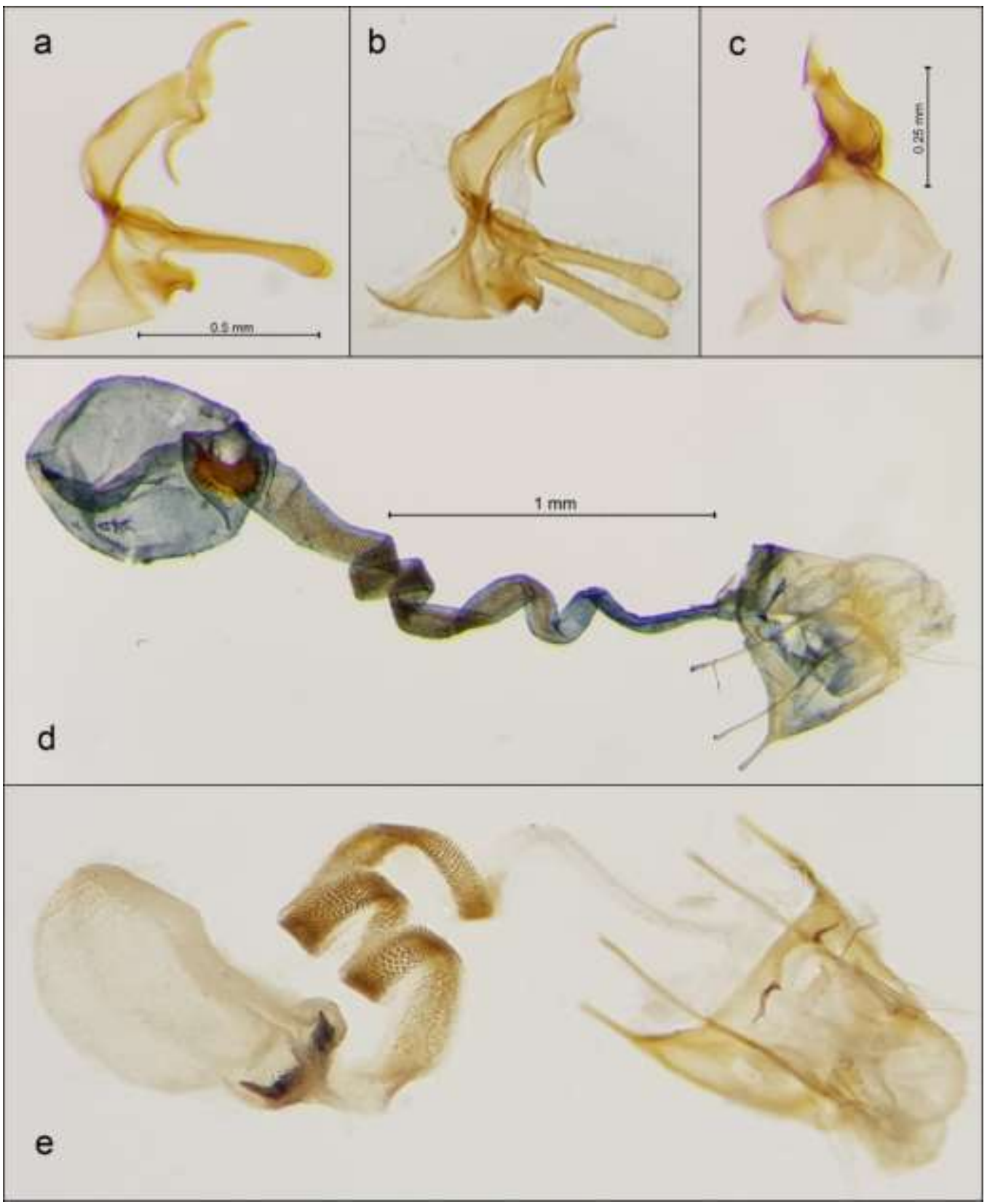

Figure 3. Genitalia of $A$. subericinella, a-c. Male genitalia (GP. 369 K. Akın), a. Total, b. Total (during preparation), c. Aedeagus, d-e. Female genitalia (GP. 367 K. Akın), d. Closed preparation after staining, e. Different view during preparation before staining. 
In literature searches on the female genitalia of A. subericinella, only one photo was found on a website called Artemisiae [13], which is a dynamic portal that aims to develop data on Lepidoptera species found in France by the association "oreina, butterflies of France". This website has been used to compare the female genitalia. Varenne and Nel [14], Kemal and Koçak [15] studies were utilized for matching the male genitalia. In the checking of adult specimens, Lepiforum e. V. [16] and Artemisiae [13] websites were also followed.

\section{Results and Discussion}

In Turkey, Aristotelia subericinella (Duponchel, 1843) was known from Amasya, Ankara, Bursa, Izmir, Siirt and Van provinces so far, as a result of this study, it is new discovered in Bitlis province and contributed to the determination of the distribution area. In addition to the known larval food plants of the species reported by Requena [8] and Robinson et al., [9], Astragalus sp. (Leguminosae) is thought to be a new larval food plant for A. subericinella. As the Lepidoptera larvae pupate mostly on the plant they feed and A. subericinella's known preference of Leguminosae species supports this idea.

Aristotelia Hübner, [1825] is a large genus and has not been revised yet. Therefore, there is difficulties in diagnosis of the species. In this study, the first identification was made according to the adult and genital of the female specimen by comparing with the available literature (see Materials and Methods). It was thought that a comparison should be made in terms of male genitalia in order to clarify the diagnosis further. However, there was only one specimen in this study and it was the female specimen. For this reason, the specimens in the collection of the Zoology Research Laboratory of Bitlis Eren University were examined and the male and female genitals of these specimens were dissected. The diagnosis of the species was confirmed after comparing the male genitalia with the male genitals in the Varenne and Nel [14] and Kemal and Koçak [15] studies. A. subericinella is similar to A. billii Varenne and Nel, 2013 and A. ericinella (Zeller, 1839) in terms of adult morphology. However, male and female genital aspects are different from these two species [14, 16,17].

The female genitalia of $A$. subericinella from Turkey, compared to the sample from France in Artemisiae website [14], the signum resembles a bean shape and is not as concave as in the French specimen. The thorns on both ends of the signum are more prominent and larger in the sample collected from Turkey. Junnilainen et al., [5] stated that A. subericinella appears to be a species complex. This study may contribute to detailed studies to be carried out on this complex in the future.

\section{Acknowledgements}

We thank Dr. Murat KÜRŞAT (Bitlis Eren University) for the identification of larval food plant of the species. We also thank Ole KARSHOLT (Denmark) for his comments on the identification of the species.

\section{Author's Contributions}

All authors contributed equally to the study.

\section{Statement of Conflicts of Interest}

No potential conflict of interest was reported by the authors.

\section{Statement of Research and Publication Ethics}

The authors declare that this study complies with Research and Publication Ethics.

\section{References}

[1] Huemer P., Karsholt O. 1999. Gelechiidae I (Gelechiinae: Teleiodini, Gelechiini). In P. Huemer, O. Karsholt and L. Lyneborg (eds): Microlepidoptera of Europe, 3: 1-356. 
[2] Karsholt O., Mutanen M., Lee S., Kaila L. 2013. A molecular analysis of the Gelechiidae (Lepidoptera, Gelechioidea) with an interpretative grouping of its taxa. Systematic Entomology, 38: 334-348.

[3] Koçak A.Ö., Kemal M. 2018. A synonymous and distributional list of the species of the Lepidoptera of Turkey. Cent. ent. Stud., Memoirs, 8: 1-487.

[4] Bidzilya O.V., Budashkin Y.I. 2015. New species of Gelechiidae (Lepidoptera) from Ukraine. Zootaxa, 3974 (2): 217-230.

[5] Junnilainen J., Karsholt O., Nupponen K., Kaitila J.P., Nupponen T., Olschwang V. 2010. The gelechiid fauna of the southern Ural Mountains, part II: list of recorded species with taxonomic notes (Lepidoptera: Gelechiidae). Zootaxa, 2367: 1-68.

[6] Mann J.J. 1861. Zur Lepidopteren-Fauna von Amasia. Wiener Entomologische Monatsschrift, 5: 183-193.

[7] Mann J.J. 1862. Verzeichniss der im Jahre 1851 bei Brussa in Kleinasien gesammelten Schmetterlinge. Tafel 3. Wiener Entomologische Monatsschrift, 6: 373-409.

[8] Requena E. 2009. Aproximació a la fauna dels gelèquids de Catalunya i Balears (Lepidoptera: Gelechiidae). Treb. Soc. Cat. Lep., 16: 5-77.

[9] Robinson G.S., Ackery P.R., Kitching I.J., Beccaloni G.W., Hernández L.M. 2010. HOSTS - A Database of the World's Lepidopteran Hostplants. Natural History Museum, London. http://www.nhm.ac.uk/hosts. (Access Date: 07.11.2019).

[10] Tatlı A. 1982. Nemrut Dağının Bitki Sosyolojisi ve Bitki Ekolojisi Yönünden İncelenmesi. Atatürk Üniv. Fen Fak. Der., 1 (1): 537-549.

[11] National Parks, 2018. Tabiat Anıtları. Doğa Koruma ve Milli Parklar Genel Müdürlügüu. http://www.milliparklar.gov.tr/korunanalanlar/ta.htm (Access Date: 07.11.2019).

[12] Robinson G.S. 1976. The Preparation of slides of Lepidoptera genitalia with special reference to the Microlepidoptera. Entomologist's Gazette, 27: 127-132.

[13] Artemisiae, 2020. Aristotelia subericinella. https://oreina.org/artemisiae/observatoire/index.php?module=fiche\&action=fiche $\& \mathrm{~d}=$ micro\&id $=246759$ (Access Date: 29.12.2020).

[14] Varenne T., Nel J. 2013. Aristotelia billii sp. n. découverte dans le Midi de la France (Lepidoptera, Gelechiidae). Revue de l'Association Roussillonaise d'Entomologie, 22 (1): 17-19.

[15] Kemal M., Koçak A.Ö. 2017. On some Microlepidoptera of Bahçesaray district (Van Province, East Turkey). Priamus, 15 (3): 125-164.

[16] Lepiforum e.V. 2019. Bestimmung von Schmetterlingen (Lepidoptera) und ihren Präimaginalstadien. http://www.lepiforum.de/ (Access Date: 07.11.2019).

[17] Wheeler J., et al. 2021. Moth Dissection UK - http://mothdissection.co.uk - V.5.1 - (Access Date: 10.03.2021). 